\title{
THE PROMISE OF PERFORMATIVE Relational, Genetic and Scripted Models in Architectural Design*
}

UDC 725.5:364.65-056.26(497.11 Banjica $)=111$

\section{Djordje Stojanovic}

\author{
University of Belgrade, Faculty of Architecture, Serbia \\ ds@4ofseven.com
}

\begin{abstract}
This paper investigates the role of performative models within the context of architectural design. Understanding the performances of the built environment can be postulated in rather different manners. It is commonly expected that the built environment complies with the diverse and changing requirements of its users. It is equally required that buildings are economically constructed, easily maintained, energy efficient, safe and aesthetically pleasing. Yet, such expectations are complex and consist of a great number of intertwined effects that are not easy to synchronize during architectural design process. Although they can be precisely evaluated and quantitatively expressed, the values specifying the performances, such as temperature, humidity and intensity of light or sound, in traditionally established course of architectural design are usually only considered throughout the post-rationalization or correction of the architectural design. The research presented in this paper explores design mechanisms, for direct and formative incorporation of feedback information into the very conception of architectural form.
\end{abstract}

Key words: performance, performative modeling, parametric modeling, genetic algorithm, custom computation, self-organization.

\section{PERFORMANCE AS A DESIGN STRATEGY}

The adjective "performative", as defined by Merriam-Webster Dictionary, is relating to an expression that serves to effect a transaction or that constitutes the performance of the specified act by virtue of its utterance. The use of the term "performance" within the context of construction industry, denotes the capacity of building materials, namely their behavior under given conditions, such as those created by atmospheric or mechanical influences. Yet, the knowledge about the performance of material developing in the field of

Received April 26, 2013

* Acknowledgement: The paper is a part of the ongoing research into the adaptive potentials of architecture at University of Belgrade and 4of7 Architectural practice. It is translated from Serbian to English Language by Jasmina Ninkov. 
building physics is first of all applied too late, in the final stages of design process and relates to post festum role in selection of material as per the personal experience or at the discretion of the designer. This study will explore a different understanding of the term "performance", associated with the development of specific design tools and strategies. Furthermore, we will try to ascertain whether such tools may help establish ways of working, based on the operative application of performative abilities of the matter to generate spatial organizations, structures and environments. The term "Performative Architecture" has been applied by Kolarević and Makawi (2003, 2005), to describe the emerging trend, which takes on the idea of performance as a guiding principle in architectural design. As perceived by two authors, one of the most intrinsic issues in the contemporary architectural design process is "the apparent disconnect between the geometry and analysis in the currently available digital design tools" (Kolarević 2005, p.3). Their position denotes the dichotomy in the understanding of the "performative" in architecture which separates between "events" and "measures" and points toward the need to establish ways of designing based on the integration between the two polarities. The goal of this study is to expand on this idea and to establish the framework for bringing the processes of geometric conception and analytical evaluation closer by developing further the idea of the performative modeling in architectural design. Moreover the paper will aim to form a theoretical platform for the development of a specific modeling technique which will be explored throughout further research.

The questions initiating the discussion about performative models in architectural design are: what are the performances of the built environment? Can they be measured and how are they applied within architectural design? Understanding the performances of the built environment nowadays can be postulated in rather different manners. It is commonly expected that the built facilities comply with the diverse and changing requirements of their users. It is universally required that buildings are economically constructed, easily maintained, energy efficient, safe and aesthetically pleasing. Yet, such expectations are complex and consist of a great number of correlated effects that are not easy to synchronize during architectural design process. Although they can be precisely evaluated and quantitatively expressed, the values specifying the performances, such as temperature, humidity, lighting or acoustic comfort, in traditionally established course of architectural design are usually only considered throughout the post-rationalization or correction of the architectural design. The research presented in this paper explores the design mechanisms for direct and formative incorporation of feedback information, generated through model evaluation, into the very conception of architectural from.

Under the umbrella term of performative models, in this paper we will consider very different forms of architectural tools which rest upon dynamic processes and continuous adaptation of the design based on the information feedback generated by evaluation of the model's performance. Such approach is based on two important assumptions. The first being the continuous interaction of the model with the environment and the second is the ability of the model to adapt on the basis of feedback information generated by such interaction. In this study the development of communicative capacity of architectural model will be discussed as a vehicle for the reorganization of the design process to provide for better assimilation of information feedback, as well as the design mechanism for achieving mutually formative relationship between the model and its environment. The development of the idea on performative modeling is presented by chronologically organized 
clarification of terms and notions which originate in different scientific fields such as philosophy, biology and mathematics, but in the more recent history have found the way into the architectural theory and practice. The review includes the notions of: self-regulation, open systems, feedback loops of information, self-organization and mutually causal relationships.

\subsection{Self-regulation}

French physiologist Claude Bernard, in the nineteenth century postulates the principle of "interior environment" (milieu intérieur) on the basis of which he later develops the concept of self-regulation, which relates to the ability of physiological systems to maintain stability or constancy of the internal organization despite the changes taking place in their environment. Claude Bernard believed that the ability of self-regulation or maintaining the stability of own temperature, chemical composition or physical structure, makes one of the basic conditions for survival of each and every living system.

\subsection{Open systems}

At the beginning of the twentieth century, the Austrian biologist Karl Ludwig von Bertalanffy, defines the principles of the "open system", the system which is in constant interaction with its environment, through exchange of energy, information and substance. Within his work on the general theory of the system Bertalanffy indicates that the principles of open systems are applicable beyond biology, in both natural and social disciplines.

\subsection{Feedback and circular causal relationships}

In mid-nineteenth century, the American mathematician Norbert Wiener published the books "Cybernetics: Or Control and Communication in the Animal and the Machine" in which he presents the idea about systems based on feedback loops of information exchange. According to this idea, the activity within some system causes the changes in its environment, which in turn cause the changes in the system itself. He indicates that the principle of circular causal relationships is visible in mechanical, physical, cognitive, sociological and biological systems, and gives an example of the ecosystem, which is based on indissoluble relationship between the living organism and their environment.

\subsection{Self-organization}

A dozen years later, the Austrian physicist Heinz von Forester, founded Biological Computer Laboratory within the Department of Electrical Engineering at the University of Illinois in Chicago, which was engaged in the research in the field of the systems theory, and developed particular interest in studying biological systems through application of computer-based processes, within which it identified the principles of self-organization, the principles of establishing the arrangement based on local interactions among the components forming that system. 


\subsection{Towards a Biological Paradigm}

What is the meaning of: self-regulation, open systems, feedback loops of information and circular causal relationships within the field of architectural design? Michael Ulrich Hensel (2010) in his essay "Performance-oriented Architecture: Towards a Biological Paradigm for Architectural Design and the Built Environment" indicates the disciplinary affiliation between biology and architecture, within which he identifies three possible approaches. The first approach is metaphorical and implies the establishment of formal similarities between the natural and built structures. The second one is analogical and is based on translation of the functional principles of biological organisms into mechanical or built solutions. And the third approach is the systemic one and is based on identification and analysis of the characteristics of biological systems which could be applied in architectural design. Michael Hensel believes that systemic approach possesses the greatest potentials, but at the same time he indicates that such interdisciplinary approach, based on the disciplinary affiliation between biology and architecture requires new techniques, research methodology and visualization, namely the new empirical forms of knowledge production and implementation of design experimentation (Hensel, 2010). All the above mentioned notions, such as self-regulation and open systems, depend on a systemic approach and development of the new architectural modeling techniques.

\subsection{Algorithm in architectural design}

In the following chapters the three ways of modeling in architectural design will have been identified. In their own ways, all three techniques presented are based on the use of algorithms in modeling process. Algorithm is a logical mechanism for problems solving which can be presented by text, scheme or computer code and which may be applied in various disciplines. Within the architectural context, Kostas Terzidis (2006) clarifies that the algorithm is a process of problem solving through a certain number of steps. According to him, that is the articulation of the strategic plan for problem solving or probabilistic search for solution. Traditionally, algorithms are applied as mathematical or logical mechanisms for practical problems solving, however, recently they have become the framework for implementation of solutions run by the computers. At the same time, Terzidis draws the attention to the fact that algorithm is also a way of thinking. According to him, algorithm is not exclusively linked to computer technology but is linked to the computation or the process of mathematical problem solving, which is essentially different from the act of entering, processing and archiving the information in computer system known as "computerization". This distinction is rather significant because it frees up, excludes and breaks up the mathematical and logical process from machine and enables execution of that process (Terzidis, 2006).

Before we embark on the discussion in the specific design techniques, it would be rather important to distinguish between the two terms which have not been explicitly translated into the Serbian language. The term "Computational Design" denotes different techniques utilizing algorithms for design problem solving and only implicitly involves the use of computer, whereas the term "Computer Aided Design CAD" denotes commercially available systems or software platforms for architectural design and explicitly implies the use of computer. Functioning of Computer Aided Design system is also based on application of algorithms; however, their understanding, to a large extent is not relevant for the use of the system. 


\section{RELATIONAL MODELING}

The widespread application of parametric modeling in architecture is linked to the emergence of software platforms which include graphic editors of algorithms. Through the application of algorithms, such tools allow for conception of architectural form based on establishing the relations between the shapes. The initial systems for Computer Aided Design CAD originated with an idea to facilitate and expedite the possibilities of the usual and traditionally established approach in architectural design, which is based on modeling by combining two-dimensional geometrical entities, such as lines, arcs, circles, triangles and polygons or three-dimensional elements such as cubes, spheres and cones. The concept of parametric modeling, on the other hand, is based on establishing the relationship between the geometric entities of the model. Instead of design by copying or combining individual geometric elements, parametric modeling is based on defining the relations between the individual elements.

In relational or parametric modeling the overall form is defined by interdependence among the entities comprising the form. The designer can control the overall model configuration through manipulation of relationships among the elements, rather than by its individual elements. The relationships themselves are defined by parameters, or measurable values which can be expressed numerically. One of the obvious advantages of such approach is the possibility to quickly adapt the models. Manipulating the relations among the elements, namely by amending the parametric values, the overall model configuration changes. Instead of upgrading the model by modification of a large number of individual components, the parametric control allows a quicker way to perceive and analyze alternative solutions.

To clarify this seemingly complex concept, Robert Aish (2005) uses a simple example of the model comprised of two tangential circles. If the tangency is accepted as the relation of these two geometrical elements, then the parametric definition of that relation reads $\mathrm{a}=\mathrm{r} 1+\mathrm{r} 2$ or the length of the line connecting the circle centers is equal to the sum of their diameters. Changing of each diameter individually causes the change of the line length, so that the geometric definitions of the tangency or relation between the two circles would be preserved (Aish, 2005). Should we establish further relation between the length of two radii $\mathrm{r} 1$ and $\mathrm{r} 2$, the entire model could be reconfigured swiftly with the change of the single parameter, the line length or either one of the two radii.

The change of parametric values allows for exploration of a large number of possible geometrical configurations. In such simple model, consisting of three entities, the saving in time achieved by parametric control versus individual elements modification is not obvious. However, if the model consists of several thousand entities parametrically controlled, as it could for example be the case with facade system with a large number of perforations, the saving in time may be significant and parametric modeling could be the only way of alternative solutions testing.

Due to the nature of parametric modeling based on definition of relationships, such approach requires an additional stage within the design process, during which stage such relationships would be established. Initially, the architect must abandon the very act of design and focus on forming the logics which allows parametric control. Creating the relationships requires additional knowledge which is not part of the traditional education in architecture (Woodbury, 2010). Initially, such skill was conditioned with the knowledge 
of programming languages; however, with the evolution of software platforms, establishment of parametric relationships was transferred to visual approach favored by the majority of architects. Today, a significant number of software solutions for three-dimensional modeling in architectural design features graphic editors which facilitate the application of algorithms in establishing the definition of parametric relationships.

"Parametrics can provide for a powerful conception of architectural form, by describing a range of possibilities, replacing in the process stable to variable, singularity with multiplicity. Using parametrics, designers could create an infinite number of similar objects, geometric manifestations of previously articulated schema of variable dimensional or operative dependencies" (Kolarević 2002, p.17). After several years of implementation of parametric modeling in his own design practice, Schumacher (2009) concludes that the paradigm of parametric modeling has become an integral part of contemporary architecture. He argues that the fundamental characteristic of parametric modeling is the implementation of the tendency formulated in the early 1990s, as a slogan "continuous differentiation" whose authors were North American theoreticians Jeff Kipnis and Greg Lynn. Schumacher points out that the concept is based on the development of tools which allows for precise formulation of the relationships between the elements and the system that they make (Schumacher, 2009).

The role of parametric modeling is not only to make possible the adaptations of models during the process of architectural design but it is also in consideration of spatial organization, structures and environments which are not based on central or hierarchical geometrical order, but on local relationships between their elements, which have been arranged through establishing the local rules. William Mitchell (1990), in his book: "The Logic of Architecture: Design, Computation, and Cognition" brings the idea on possibilities of describing and conception of spatial organizations closer, through application of rules, which like spoken language grammatical rules form the mechanism for establishing a structure. He describes the concept of "shape grammar", postulated earlier by George Stiny and James Gips (1972), as an explicit application of syntax and grammar of the formal language in the process of architectural design. By analyzing a number of classical texts, Mitchell points out that traditional understanding of architectural form is based on application of rules, such as symmetry, rhythm, proportions and particularly refers to the book by Owen Jones $(1856,2001)$ titled "Grammar of the Ornament", where the thesis was developed that form may not be obvious, but that there is a proportionality between that which we accept as beautiful and the mental effort required for detecting such structural rules. It is significant that prior to expansion of computer technology, Mitchell (1972) presents his opinion that the systems for Computer Aided Design provides a new language of architecture, which is based on algorithmic logic and which seeks to establish the new and more complex spatial organizations, structures and environments. On the one part, Mitchell's ideas may be seen as a precursor of parametric or relational modeling, and on the other part as a precursor for the development of much broader spectrum of algorithm-based approach in the conception of spatial environments. 


\section{GENETIC ALGORITHMS}

Development of application of genetic algorithms, primarily in technical problems solving, started in mid-twentieth century. During the 1970s John Holland published the book "Adaptation in Natural and Artificial Systems" in which he promotes the idea on genetic algorithms and develops the thesis that their understanding has a broader significance and role in the study of complex adaptive systems, characterized by a large number of nonlinearly conditioned parameters. Holland points to the possible application of genetic algorithms in rather different fields, such as economics and psychology.

In his book "Evolutionary Architecture", John Frazer (1995) deepens the idea of the possibilities of instrumentalisation of natural processes and systems organization within the field of architectural design, by applying computer aided modeling techniques. According to him "the natural ecosystems have complex biological structures: they recycle their material, permit change and adaptation, and make efficient use of the ambient energy. By contrast most man-made and built environments have simple and incomplete structures: they do not recycle, are not adaptable and waste their energy" (Frazer 1995, p.16). In his book "Architecture in the Digital Age: Design and Manufacturing", Branko Kolarević (2002) elaborates on the research conducted by Frazer during the 1990s at the University of Cambridge and at the School of Architecture within the Architectural Association in London, and he himself points out that the concepts of biological growth and form, like evolutionary model in nature, can be applied in architectural design. The mechanism for application of evolutionary model in architectural design, described by both authors, consists of a series of "generative rules" which are structured in the form of a series of instructions, making computer script or program (Kolarević, 2002 p.23). The approach to design advocated by Frazer (1995 p.12) suggests "the production of a series of prototypical forms, which are evaluated according to their own performances within simulated environment".

The use of genetic algorithms is based on the principles of biological evolution, according to which the selection of the species of the living organisms in the natural world takes place. More precise formulation establishes the application of genetic algorithms as a method of optimization that comprises the processes of population, mutation, reconfiguration and selection (Hoffmeister and Back, 1991). In the frame of the research of the methods of structural optimization of grid shells, Dimčić (2011) states that the way of application of genetic algorithms does not differ significantly from traditionally established logic of architectural design process, and that it can be summarized in five steps consisting of: consideration of a series of possible solutions, selection of the acceptable solutions, combining the upgraded solution to achieve the new ones, and the last step which involves the repetition of the above stated procedure until satisfactory or optimal results have been achieved (Dimčić, 2011). The essential advantage of the application of genetic algorithms lies in examination of a larger number of possible options to find the best solution. The optimization process is automated and it is based on a series of algorithmic rules structured in the form of the chain which is equivalent to chromosome structure which enables the process of genetic mutation, reconfiguration and selection, after which the logic and the very modeling techniques name originate from.

The application of genetic algorithms in technical problems solving which involve different forms of structural optimizations, presents a useful an exciting field of research. 
However, within this study it is dealt with the issues of development of specific approach within the field of architectural design and the focus is on the issues which primarily relate to design techniques and methodology which enable the development of adaptive principles in the conception of spatial organizations. In such context we can consider the ways of applying the knowledge and techniques from other disciplines, within the field of architectural design.

Biomimetics or biomimicry is an interdisciplinary study that deals with the study of biological systems and the application of thus acquired knowledge in development of materials and technology. The issue of application of biological knowledge within the field of architectural design, directly during the conception and realization of spatial organizations, is central to the educational program founded by Michael Hensel, Achim Menges and Michael Weinstock at the Architectural Association in London. Today, similar research is carried out at The Research Center for Architecture and Tectonics RCAT in Oslo and at The Institute for Computational Design ICD in Stuttgart and at many other schools. One of the key topics of such research relates to the conception and realization of the spatial organizations, structures and environments possessing functionality and performative capacities of biological organisms (Hansel, 2006). In the first section of this study, it has been pointed out to the potential of disciplinary affiliation between biology and architecture and the idea of the systemic approach in interdisciplinary research has been identified. Once again, we can bring forward that such idea is based on the analysis of the characteristics of the biological systems which could be applied directly in architectural design. Very much like previously described framework established in the 1970s by Heinz von Foerster who founded the Biological computer laboratory in Chicago, in order to study the biological systems through the application of computer aided processes, the above mentioned architectural laboratories in London, Stuttgart and Oslo, nowadays investigate biological processes as a model of spatial organization based on the local interaction between the components that make the system, namely the self-organization principles.

Kauffman (1993) clarifies the phenomenon of self-organization as a process of spontaneous establishment of organization which enables adaptation of many complex biological systems and makes the backbone of the theory of evolution. Such systems are characterized by emergent properties, which cannot be comprehensively understood through individual analysis of constituent elements but only through consideration of the interaction among them, as well as the interaction of that system and its environment (Cilliers, 1998). Kauffman points out that the idea on self-organization goes beyond the limits of biology and has the application in contemporary sciences, in mathematics, physics and chemistry. Hansel believes that the principle of self-organization as a process in which internal system organization is established without external influences can be translated to strategic consideration at the level of architecture (Hansel, 2006).

One of the many possible strategic interpretations of the notion of self-organization in architecture relates to the ability of the substance to adapt its structure in order to take a stable configuration under the influence of external force. Weinstock (2006) points out that Antonio Gaudi, Heinz Isler, Frei Otto and many other architects and engineers exploited such principles of formation by applying the analogous methods of modeling. He believes that the issue of form makes the central subject of study in theory and practice throughout the history of architecture, and points to the development of re-configured 
conception of nature within the modern architectural discourse, according to which the question of form is directly linked to the question of its performances: how is it illuminated? How does it ventilate? How does it enable the flow and transport? How is it heated and how it retains heat? Weinstock reminds that in the biological world the form is the direct consequence of metabolism, that the energy and substance fully determine the form of the living organisms (Weinstock, 2008).

\section{THE CUSTOM PROGRAMMING AND THE USE OF COMPUTER LANGUAGES IN ARCHITECTURE}

Similar to the previously described use of genetic algorithms and the technique of parametric modeling, use of custom programming allows for the formulation of the design strategies based on the algorithmic logic. The discussion on the role of programming languages in architecture is partially based on the wiki text, created through collaboration and joint contribution of the users of Processing, a computer language. Credit for both initiatives, for the creation the programming language and the text, belongs to Ben Fry and Casey Reas. However, this study is not limited to the specific features of a single programming language but rather relates to one entire architectural paradigm based on the use of computer programming in architecture. Other computer languages that find their application within the field of architectural design are: Python, rhinoScript, Visual Basic Script, $\mathrm{C}++$ and Maya Embedded Language MEL.

Processing was created to develop visual ideas through computer programming. Its code is an open source; it is publicly available and is used as a tool for creating images, animation and interactive forms of visual arts. In architecture it is used for initiation of design ideas, which can be developed further through the use of other programming languages or systems for computer aided design. One potential role of the programming language in architecture is to help study complex spatial organizations, whose understanding is rests upon handling of vast quantities of data generated by the interactive processes that take place in real time. Processing, just like many other programming languages, enables the strategy of object-oriented programming OOP. The approach is based on the establishment of structures through the regulation of the local relationships, namely interaction and exchange of information among the objects forming that structure. In architecture, just like in programming, object-oriented approach enables planning of structures that emerge on the basis of accumulation of the relationships within large population of objects or "software agents" characterized by a certain level of intelligence, namely the ability to make their own decisions. Such systems, called Multi Agent Systems MAS find their application in different disciplines, such as social sciences or economics.

In relation to what is suggested as a guiding principle of self-regulation in biological systems, the object-oriented approach in planning could be the way of better understanding of complex spatial organizations. An early example of such model was created by Craig Reynolds (1986) in the form of computer simulation of "swarm behavior", the phenomenon which in the world of biology explains the grouping and movement of a large number of organisms, such as bird flocks or fish schools. Reynolds' algorithmic model is based on the principals of collective intelligence, established through the use of three simple steering rules which regulate the behavior of each agent within that swarm or col- 
lective. In this case such simple rules are: Separation or steer to avoid crowding local flock mates, Alignment or steer towards the average heading of local flock mates and Cohesion or steer to move toward the average position of local flock mates (Reynolds, 1986). When simple rules are structured in the form of algorithms and applied to a large number of objects, complex spatial organizations can be equally produced in architectural context.

The use of custom programming in architecture enables the conception of form by simulation of formative processes which lead to its formation. Models created by using algorithms are based on relations, they are not static, but dynamic and capable of adaptation to changes of the internal relationships among its elements or to the external forces being imposed upon them. A common approach in architecture and many other disciplines, is the one known as "particle systems". The strategy relies on the large quantities of particles whose movement, same as in physical world, is determined with a sequence of mutually interlocked laws of nature which are established through algorithmic definitions. A good example of such modeling technique would be the one developed by Axel Kilian after Gaudi's model established at the turn of the twentieth century. Such example denotes the possibility of translating physical modeling technique, together with all complexities including characteristics of material and effects of the laws of chemistry and physics, into significantly more efficient technique based on digital technology, exactly through application of the particle systems (Killian 2004).

Compared to previously described techniques consisting of parametric modeling and the use of genetic algorithms, custom programming also provides for the better exchange of information and the establishment of feedback loops between the model and its environment, in addition to adaptability of the model. Exactly the way in which it was suggested by Weiner in mid-twentieth century, through an idea on circular causal relationships between the system and its environment, the models whose logical structure is based on algorithmic rules, which were established through application of programming languages, can be adapted according to the information generated through interaction of the model and its environment.

The possibilities of application of multi-agent systems to establish exchange of information and feedback loops during architectural modeling may be linked to the problems of different scales. It can relate to the behavior and requirements of a large number of users, or on quite different level it can relate to molecular phenomena that occur in building materials. In regards to architecture, one of the most important potentials of the use of programming languages lies in combining digital and analogous mechanisms, or in other words, in connecting the physical with the digital environment. The models created through the use of programming languages may hold the potential to integrate a variety of information which otherwise could only be presented by simultaneous use of a larger number of media such as tables, drawings, images, video and audio recordings. Such models may hold the key to broader and more comprehensive understanding of performance in architecture.

In the previous paragraph we have pointed at a development of a specific modeling technique, based on the particle the systems and used to simulate the behavior of building materials under the influence of structural forces. This principle is equally applicable to other aspects of performance, as feedback loops or exchange of information, which may relate to the efficient use of the energy and can be expressed through the processes such as convection, conduction, evaporation or radiation (Rahm, 2009). 


\section{EPISTEMOLOGICAL CLARIFICATION OF THE SIMULATION ROLE IN ARCHITECTURAL DESIGN}

In conclusion we will look at the epistemological role and significance of the model in architectural design and other disciplines. Computer modeling or simulation was initially defined as specific type of a dynamic model, which comprises the evolution of the observed system over time. Yet, understanding the role of simulation in the process of cognitive development is much more complex today. Franck Varenne believes that the general effect of computer-based turn in engineering sciences and architectural design is reflected in the marginalization of the mathematical model, in favor of programming languages, formalism and systems. Particular contribution of the computer turn is the increase in the capacities of the designed systems to build heterogeneous relationships towards things, physical properties, functions, environments and other designed systems or values (Varenne, 2010).Varenne suggests that such systems build the new materiality, owing to the comprehensive approach which involves a multitude of submodels which describe the subject of study (Varenne, 2012). From the standpoint of the history of epistemology, Varenne draws attention to the fact that the application of programming languages has the potential to transform traditionally established courses of knowledge development in many disciplines. He identifies the problem of "new materiality", which is based on more extensive and thorough understanding of the world around us and points to specific significance which modeling techniques have, among which is also the simulation technique (Varenne, 2010).

Varenne particularly emphasizes that the use of Multi Agent Systems MAS and other types of simulation enable the modeling aspects which simultaneously include observations, descriptions and proscriptions (Varenne, 2012). He reminds that empirical sciences are based on methodological observations, research and experimentation. In such context, experiment represents the method of testing which is conducted to clarify some phenomenon. On the other part, Varenne continues, theoretical approaches based on modeling, are perceived as based on conceptual or hypothetical-deductive approach. Originally, the role of the scientific model is epistemologically determined on the basis of systematic comparison with theory. Such models are not accepted as autonomous, but as derivatives that are generated from theory, whose role is to establish the structure and relationships which represent certain theory. However, within the research, which at the same time includes observations, descriptions and proscriptions, the role of the model comes closer to the role of the experiment, and the model is accepted as "autonomous mediator" (Morgan, 1999) "between the theory, practice and experimentally determined data" (Phan and Varenne, 2010).

In other words, the arguments developed by Phan and Varenne (2010), relate to the move of the epistemological status of the model through inclusion of simulation in the modeling process. This statement is illustrated by the observations that in the social sciences, in addition to inductive and deductive methods, simulation represents "the third way of being engaged in science"(Axelrod, 1997). In social disciplines, simulation is considered as a form of scientific research, which differs from modeling, and as per its character comes closer to the research through experiments, just because of the exact, direct and formative impact of information upon the subject of study. If we accept that the use of performative modeling may have equally significant impact upon the development of the novel workflows in architectural design, then we may consider further questions related to 
the very core of the discipline. We may consider, if the application of performative modeling which includes algorithmic understanding of physical and material processes may now provide for the revised role of material performances in the conception of spatial organizations, structures and environments.

\section{REFERENCES}

1. B. Kolarević, Architecture in the Digital Age: Design and Manufacturing, Spon Press (Taylor and Francis), London and New York, 2003.

2. B. Kolarević, and A. Malkawi, Performative Architecture: Beyond Instrumentality, Spon Press (Taylor and Francis), London and New York, 2005.

3. M. Hensel, "Performance-oriented Architecture - Towards a Biological Paradigm for Architectural Design and the Built Environment", FORMAkademisk Volume 3 (1), 2010, pp 36-56.

4. K. Terzidis, Algorithmic Architecture, Architectural Press an imprint of Elsevier, Oxford, 2006.

5. R. Aish, and R, Woodbury, "Multi-level Interaction in Parametric Design", Lecture Notes in Computer Science Volume 3638, 2005, pp 151-62.

6. R. Woodbury, Elements of Parametric Design, Routledge, London, 2010.

7. P. Schumacher, "Parametricism - A New Global Style for Architecture and Urban Design", in Digital Cities, N. Leach Ed. Architectural Design Volume 79(4). London: Wiley and Sons, 2009, pp. 14-23.

8. G. Stiny, and J. Gips, "Shape grammars and the generative specification of painting and sculpture", Information Processing No 71. Amsterdam and New York: North-Holland Publishing Company, 1972, pp. $1460-65$.

9. W. J. Mitchell, The Logic of Architecture: Design, Computation, and Cognition, MIT Press, Cambridge, Massachusetts, 1990.

10. Jones, Grammar of the Ornament (1856), Herbert Press, London, 2001.

11. J. Holland, Adaptation in Natural and Artificial Systems: an introductory analysis with applications to biology, control, and artificial intelligence (1975), MIT Press, Cambridge, Massachusetts, 1992.

12. J. Freiser, An Evolutionary Architecture, Architectural Association Publications, London, 1995.

13. F, Hoffmeister F. and T. Back, "Genetic Algorithms and Evolution Strategies: Similarities and Differences" Lecture Notes in Computer Science 496, 1991, pp. 681-89.

14. M. Dimčić, Structural Optimization of Grid Shells based on Genetic Algorithms PhD Thesis, ITKE, Stuttgart University, 2011

15. M. Hensel, "Synthetic Life-Architectures - Ramifications and Potentials of a literal Biological Paradigm for Architectural Design", in Techniques and technologies in Morphogenetic Design, M. Hansel, A. Menges and M. Weinstock., eds. Architectural Design Volume 76(2). London: Wiley Academy, 2006, pp.18-25.

16. S. A. Kauffman, the Origins of Order Self-Organization and Selection in Evolution, Oxford University Press, Oxford, 1993.

17. P. Cilliers, Complexity and postmodernism: Understanding complex systems, Routledge, London and New York, 1998.

18. M. Weinstock, "Self-organization and material constructions", in Morphogenetic Design, M. Hansel, A. Menges and M. Weinstock., eds. Architectural Design Volume 76(2). London: Wiley Academy, 2006, pp. 34-41.

19. M. Weinstock, "Metabolism and Morphology" in: Versatility and Vicissitude: Performance in MorphoEcological Design, M. Hansel and A. Menges eds. Architectural Design Volume 78(2), London: Wiley Academy, 2008, pp. 26-33.

20. B. Fry, C. Reas et al. "Processing Architecture", 2001 [online], available at: $<$ http://wiki.processing.org/w/Processing_Architecture $>$ [Accessed 14 February 2013].

21. C. W. Raynolds, "Boids", [online] 1986, available at: $<$ http://www.red3d.com/cwr/boids/> [Accessed 14 February 2013]

22. C. W. Raynolds, "Flocks, herds and schools: A distributed behavioral model", Computer Graphics 21 (4), 1987, pp. 25-34.

23. Kilian, "Linking Digital Hanging Chain Models to Fabrication, Fabrication: Examining the Digital Practice of Architecture", Proceedings of the 23rd Annual Conference of the Association for Computer 
Aided Design in Architecture and the Conference of the AIA Technology in Architectural Practice Knowledge Community, Cambridge (Ontario) 8-14 November 2004, pp. 110-125.

24. P. Rahm, "Towards a meteorological architecture", 2009 [online] available at: $<$ http://www.philipperahm.com/data/rahm-office.pdf > [Accessed 14 February 2013].

25. F. Varene F. and D. Phan, "Agent-Based Models and Simulations in Economics and Social Sciences: from conceptual exploration to distinct ways of experimenting", Journal of Artificial Societies and Social Simulation JASSS, Number 13(1) 5, 2010 [online], available at: $<$ http://jasss.soc.surrey.ac.uk/13/1/5.html $>$ [Accessed 14 February 2013].

26. R. Axelrod, "Advancing the Art of Simulation in the Social Sciences" in: Simulating Social Phenomena R. Conte, R. Hegselmann, and P. Terna, eds., Berlin: Springer-Verlag, 1997, pp. 21-40.

27. M.S. Morgan, and M. Morrison, Models as Mediators, Cambridge University Press, Cambridge Massachusetts, 1999.

\section{PERFORMATIVNI MODEL \\ Relacioni, genetski i kodirani pristupi u arhitektonskom projektovanju Djordje Stojanović}

Ovaj rad istražuje ulogu performativnog modela u procesu arhitektonskog projektovanja. Razumevanje performansi izgrađenog okruženja možemo postaviti na veoma različite načine. Danas očekujemo da izgrađeni objekti budu usklađeni sa različitim i promenljivim potrebama svojih korisnika, da budu ekonomično izgrađeni, pogodni za održavanje, energetski efikasni, bezbedni i estetski ugodni. Međutim, ovakva očekivanja su složena i sastoje se od velikog broja međusobno povezanih uticaja koje nije lako uskladiti tokom arhitektonskog projektovanja. Iako mogu biti precizno evaluirane i izražene kvantitativnim putem, vrednosti koje određuju performanse, kao što su temperatura, vlažnost, intenzitet svetlosti ili zvuka, u tradicionalno uspostavljenom toku arhitektonskog projektovanja se najčešće primenjuju samo za naknadnu racionalizaciju ili delimičnu korekciju arhitektonskog projekta. Predmet istraživanja ove studije se odnosi na mehanizme za neposredno i formativno uključivanje povratnih informacija, koje nastaju putem evaluacije modela, u sam tok koncepcije arhitektonske forme.

Ključne reči: performanse, performativni model, parametarsko modelovanje, genetski algoritam, namensko programiranje, samo-organizacija. 